\title{
PENTINGNYA DIGITAL MARKETING DALAM MEMAJUKAN UMKM DI MASA PANDEMI COVID-19
}

\author{
Erfan Efendi*, Nurani Damei Ati, Emma Sukma Zulmida, Cindy Nur Chofifah, \\ Fitria Afdiyanti Astuti, Rosalina Dwi Amara, Selva Fersa Sonia \\ Fakultas Ekonomi dan Bisnis, Universitas Islam Malang \\ *korespondensi email: erfanefendi@unisma.ac.id
}

\begin{abstract}
ABSTRAK
Sektor perekonomian adalah salah salah satu sektor yang terdampak Pandemi covid-19 yang terjadi di seluruh dunia, termasuk Indonesia. Upaya pemerintah untuk mencegah penyebaran virus dengan menerapkan Pemberlakuan Pembatasan Kegiatan Masyarakat (PPKM), yang berdampak pada berkurangnya mobilitas kegiatan masyarakat. Dengan adanya kegiatan PPKM ini banyak pemilik UMKM merasa rugi. Salah satu pemilik UMKM yang merasakan dampaknya yaitu Saudara Muhayan selaku pemilik usaha "Bina Ternak Lancar Jaya" yang bergerak dibidang peternakan ayam potong di Desa Randuagung, Singosari, Kab. Malang, tempat kami melakukan KSM-Tematik. Sepinya pasar adalah salah satu dampak yang didapatkan sehingga berpengaruh terhadap turunnya omset. Untuk tetap dapat mempertahankan keberlangsungan usahanya, dimasa pandemi ini pemilik UMKM dituntut untuk bisa menyesuaikan dengan keadaan yang terjadi dan selalu mengikuti perkembangan zaman salah satunya dengan mengubah cara pemasaran produk dengan menggunakan metode digital marketing sehingga tanpa bertemu dengan konsumen penjual dapat menawarkan produknya, jangkauan pemasarannya pun dapat lebih luas. Selain itu digital marketing juga mempermudah bagi pelaku UMKM dalam pengefektifan biaya dan transaksi lebih mudah bisa dilakukan dimana saja dan kapan saja. Tidak hanya itu para pemilik usaha juga harus memiliki ciri khas pada produknya agar lebih dikenali dengan mudah oleh konsumen dan berbeda dengan yang lain salah satunya dengan cara memberikan Brand/Merk yang menarik pada produk. Dan untuk mengambil keputusan yang sesuai dengan masalah yang dihadapi selama pandemi pelaku usaha perlu membuat pencatatan akuntansi sederhana untuk mengetahui arus kas yang terjadi.
\end{abstract}

Kata Kunci: pandemi covid; UMKM; digital marketing

\section{PENDAHULUAN}

Corona Virus Disease atau yang lebih dikenal dengan COVID 19 adalah sebuah virus yang mewabah di seluruh dunia. Awal mula virus ini ditemukan yaitu di daerah Wuhan, China pada tahun 2019. Perkembangan virus ini sangat cepat menyebar ke seluruh dunia dan tak sedikit juga dampak yang disebabkan karena adanya virus ini. Pandemi covid memberikan dampak yang luar biasa pada bidang kehidupan masyarakat dunia, termasuk di Indonesia, baik dalam bidang sosial, politik maupun ekonomi (Pakpahan, 2020; Sumarsono et al., 2021). Upaya pemerintah dalam menghambat penyebaran Covid ini juga menghambat kegiatan perekonomian masyarakat. Salah satu yang dilakukan pemerintah yaitu adanya pembatasan aktifitas masyarakat yang menimbulkan kerugian ekonomi yang 
signifikan (Hadiwardoyo, 2020). Beberapa sektor yang terdampak Covid 19 yaitu, sektor kesehatan, perdagangan, transportasi dan rumah tangga (Susilawati et al, 2020).

Sektor yang paling terkena dampak Pandemi Covid 19 adalah UMKM (Usaha Mikro Kecil dan Menengah). Ribuan pelaku UMKM melaporkan dampak serius yang diakibatkan adanya pandemi ini. Usaha mereka dilaporkan mengalami penurunan sampai sebesar 56\%. Selain mengalami penurunan pendapatan, para pelaku UMKM juga mengaku bahwa mereka sulit mendapatkan pembiayaan, distribusi, sampai bahan baku dari akibat adanya pandemi yang tak bisa dipastikan (Pakpahan, 2020). Banyak para pelaku UMKM yang mengalami penurunan bahkan pailit pada usahanya, tapi tak sedikit juga para pelaku UMKM bangkit dan pulih untuk menghadapi pandemi. Mereka bangkit dan berani untuk beradaptasi mengahadapi pandemi dengan membuat rancangan dan strategi baru dalam usahanya (Brown and Rocha, 2020; Sari et al., 2021). Salah satu alternative yang dapat dilakukan para pelaku usaha yaitu dengan memanfaatkan Digital Marketing untuk tetap mempertahankan dan mengembangkan usahanya terutama selama pandemi.

Pekembangan teknologi yang semakin canggih saat ini memang tak bisa dihindari. Semua hal saat ini dapat dilakukan menggunakan internet dan serba digital, termasuk dalam hal pemasaran. Strategi pemasaran digital yang mulai menjadi trend ini lebih prospektif karena memungkinkan para calon pembeli atau konsumen untuk memperoleh segala informasi mengenai produk yang diinginkan dan bertansaksi melalui internet. Digital marketing adalah sebuah aktivitas pemasaran yang menggunakan berbagai media online, seperti e-mail, website, blogs dan beberapa media sosial (Ridwan Sanjaya dan Joshua Tarigan, 2009). Penerapan digital marketing menggunakan social media seperti Facebook, Whatsapp, Instagram dan social media lainnya dapat meningkatkan pendapatan yang signifikan. Selain itu, penggunaan social media juga dapat memudahkan para pelaku UMKM untuk memasarkannya terutama di masa Pandemi saat ini (Pradiani, 2017). Melalui digital marketing, para pelaku UMKM dapat melakukan pemasaran produk dan transaksi yang juga dilakukan secara online. Media sosial menjadi sarana yang dapat dimanfaatkan untuk perkembangan dan keberlangsungan UMKM. Selain biaya yang murah dan tidak perlu keahlian khusus untuk melakukannya, media sosial dianggap mampu menjangkau calon pembeli secara langsung (Husni \& Farida, 2020).

Berdasarkan uraian tersebut, mahasiswa dari kelompok 8 KSM Tematik (Kandidat Sarjana Mengabdi) Universitas Islam Malang 2021, melaksanakan kegiatan pembelajaran pemberdayaan masyarakat untuk menyalurkan ilmu untuk mewujudkan masyarakat yang inofatif dan berkembang. Melihat dari permasalahan tersebut, program kegiatan pembelajaran pemberdayaan masyarakat yang dilaksanakan adalah memanfaatkan penggunaan digital marketing untuk memajukan UMKM selama pandemi.

\section{METODE}

Metode yang kami gunakan dalam melaksanakan program kegiatan ini adalah metode partisipatif. Metode partisipatif yaitu metode yang melibatkan atau mengikutsertakan seseorang (individu atau warga masyarakat) dalam suatu kegiatan tertentu (Theodorson, 1994). Program kegiatan pembelajaran yang dilaksanakan adalah pengembangan UMKM melalui Digital Marketing dan sosialisasi pencatatan akuntansi sederhana. Setelah melakukan survei, kami menemukan bahwa usaha UMKM tersebut kurang dalam mengikuti perkembangan teknologi sehingga pemasaran hanya mencakup di lingkungan sekitar. UMKM tersebut adalah usaha peternakan ayam potong yang dimiliki oleh Muhayan. Kami juga berbincang dengan pemilik usaha ternak mengenai beberapa kendala yang dialami selama keberlangsungan usaha tersebut di era pandemi. Salah satu kendalanya yaitu pasar yang mulai sepi, sehingga menyebabkan harga ayam relatif turun. 
Kemudian kami menyarankan kepada pemilik untuk melakukan pemasaran melalui digital marketing. Setelah pemilik usaha UMKM menyetujui, kami membuat media sosial sebagai media pemasaran bagi usaha ternak yaitu melalui Facebook dan Instagram. Tak hanya itu, kami juga membuatkan logo sebagai identitas usaha supaya lebih dapat dikenal oleh para konsumen. Kami juga mengedukasikan kepada saudara Muhayan sebagi pemilik UMKM mengenai pencatatan akuntansi sederhana.

\section{HASIL DAN PEMBAHASAN}

Hasil pengabdian yang dilakukan oleh Kelompok 8 KSM UNISMA kepada UMKM Bina Ternak Lancar jaya bisa berjalan dengan lancar. Berikut ini adalah hasil-hasil yang diperoleh dari kegiatan tersebut.

\section{Survei dan Kunjungan ke tempat UMKM}

Tahap pertama yang dilakukan yaitu melakukan survei ke desa Randuagung untuk menemui pemilik salah satu UMKM yaitu saudara Muhayan selaku pemilik UMKM peternakan ayam potong. Pada tahap ini, pelaksana kegiatan melakukan kunjungan UMKM untuk mengetahui bagaimana kondisi usaha tersebut dan berbincang mengenai bagaimana perkembangan usaha tersebut selama pandemi. Setelah didapatkan informasi dari pemilik, diketahui bahwa dampak pandemi cukup mempengaruhi keberlangsungan usaha tersebut. Pemilik UMKM mengatakan bahwa semenjak pandemi, pasar mulai sepi dan menyebabkan harga ayam relatif turun.

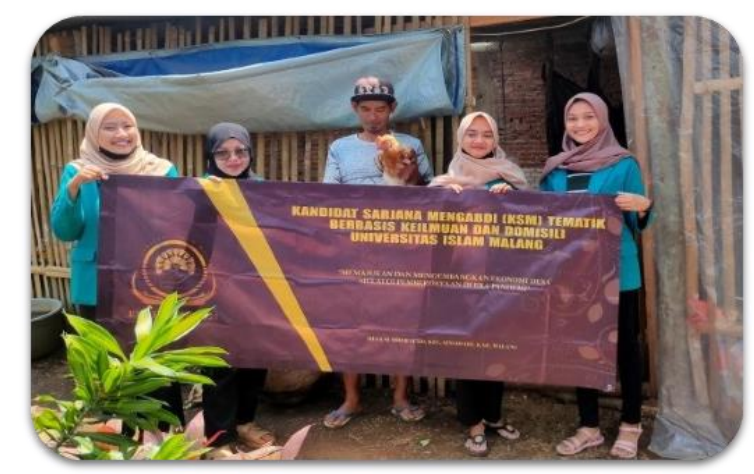

Gambar 1.

\section{Sosialisasi Digital Marketing dan Pencatatan Akuntansi Sederhana Dengan Pemilik UMKM}

Tahap yang kedua yaitu melakukan sosialisasi kepada saudara Muhayan mengenai digital marketing sebagai upaya untuk menyesuaikan kedaan dan mengikuti perkembangan zaman sehingga produk dapat dipasarkan lebih mudah dan lebih luas. Dan juga kami melakukan sosialisasi pencatatan akuntansi sederhana untuk membantu pemilik dalam mengawasi arus kas yang terjadi pada usahanya dan mempermudah dalam pengambilan keputusan atas keberlangsungan usahanya. 


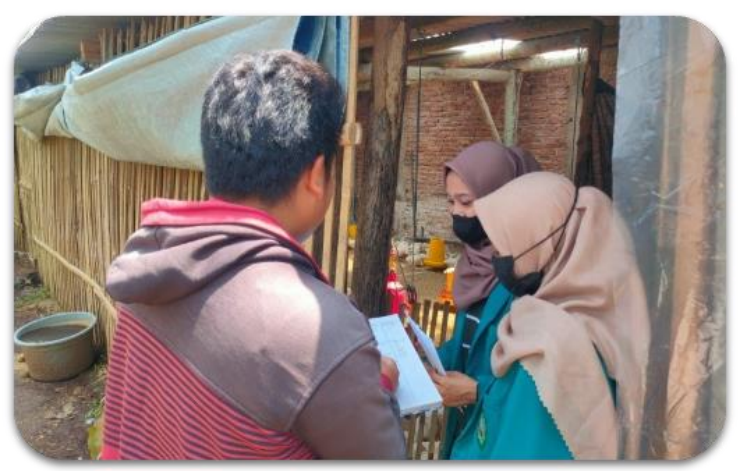

Gambar 2.

\section{Mendesain Logo Serta Pembuatan Sosial Media}

Tahap yang terakhir adalah mendesain logo agar produk dapat dengan mudah dikenali oleh masyarakat. Kelompok kami juga membantu pemilik membuat sosial media yaitu berupa Instagram dan Facebook sebagai media bagi pemilik usaha untuk memasarkan produknya dan mempermudah proses transaksi dengan para konsumen.
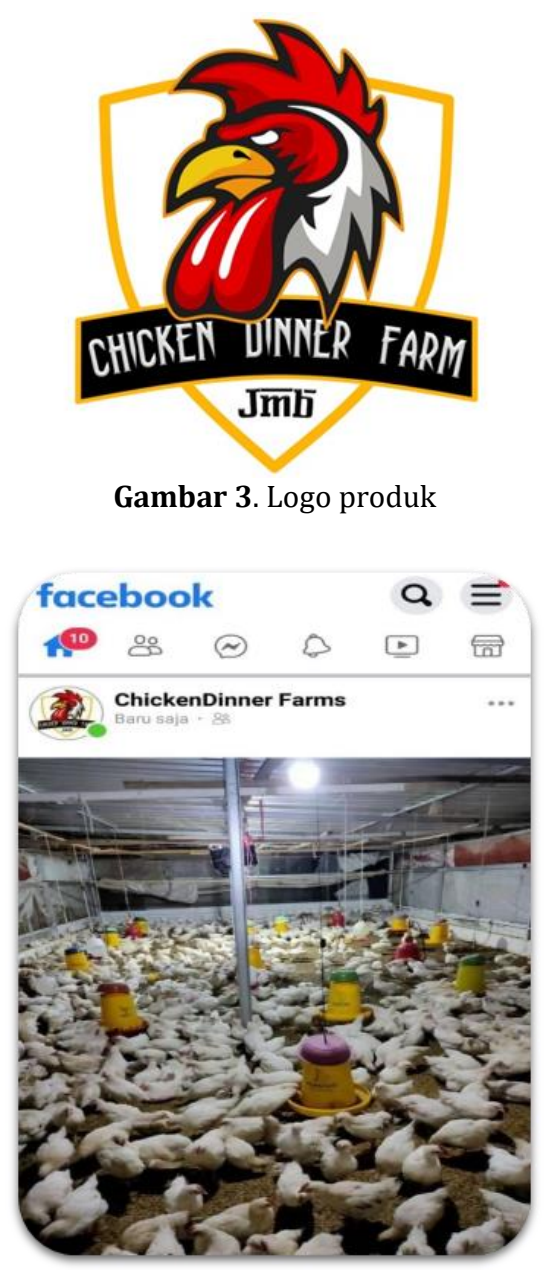

Gambar 4.

\section{KESIMPULAN}

Meskipun dampak pandemi cukup berpengaruh terhadap perekonomian, hal tersebut tak menyurutkan peluang bagi para pelaku UMKM untuk terus mengembangkan dan memajukan usahanya. Pelaku usaha harus dapat menyesuaikan kegiatan usaha dengan 
keadaan yang sekarang terjadi. Salah satunya yaitu dengan mengikuti perkembangan zaman dan memanfaatkan kecanggihan teknologi untuk menerapkan digital marketing sebagai sarana untuk memasarkan produk secara online. Dengan begitu beberapa manfaat yang didapat bagi pelaku UMKM yaitu biaya promosi yang lebih murah, dapat menjangkau pelanggan atau konsumen secara langsung, transaksi jual beli dapat dilakukan dimana saja dan kapan saja tanpa harus bertatap muka.

\section{UCAPAN TERIMA KASIH}

Terimakasih disampaikan kepada Muhayan selaku pemilik UMKM, teman-teman kelompok 8 KSM UNISMA atas bantuan dan dukungannya dalam pelaksanaan kegiatan KSM Tematik 2021, serta pihak LPPM (Lembaga Penelitian dan Pengabdian Masyarakat) Universitas Islam Malang.

\section{DAFTAR RUJUKAN}

Abdurrahman, G., Oktavianto, H., Habibie, E. Y., \& Hadiyatullah, A. W. (2020). Pelatihan Digital Marketing Pada UMKM Sebagai Penunjang Kegiatan Promosi dan Pemasaran. Jurnal Pengabdian Masyarakat, 88-92. Retrieved from http://jurnal.unmuhjember.ac.id/index.php/manage/article/view/3981

Andriany, D. (2015). Pengembangan Model Pendekatan Partisipatif Dalam Memberdayakan Masyarakat Miskin Kota Medan Untuk Memperbaiki Taraf Hidup . SEMINAR NASIONAL EKONOMI MANAJEMEN DAN AKUNTANSI (SNEMA), 30-39. Retrieved from http://fe.unp.ac.id/sites/default/files/unggahan/3.\%20Dewi\%20Andriany\%20\%28hal\%20 30-39\%29_0.pdf

Awali, H., \& Rohmah, F. (2020). URGENSI PEMANFAATAN E-MARKETINGPADA KEBERLANGSUNGAN UMKM DI KOTA PEKALONGAN DI TENGAH DAMPAK COVID-19. Jurnal Ekonomi dan Bisnis Islam, 1-14. Retrieved from https://ejurnal.iainpare.ac.id/index.php/balanca/article/view/1342/711

Hapsoro, B. B., Palupiningdyah, P., \& Slamet, A. (2019). Peran Digital Marketing sebagai Upaya Peningkatan Omset Penjualan Bagi Klaster UMKM di Kota Semarang. Jurnal Abdimas, 117-120.

Retrieved

from https://journal.unnes.ac.id/nju/index.php/abdimas/article/view/17880

Oktaviani, F., \& Rustandi, D. (2018). Implementasi Digital Marketing dalam Membangun Brand Awareness. Profesi Humas, 1-20. Retrieved from http://jurnal.unpad.ac.id/profesihumas/article/view/15878

Sari, W. E., Yulianto, Junirianto, E., Franz, A., Karim, S., \& Khamidah, I. M. (2021). Video branding untuk promosi usaha mikro kecil menengah (UMKM). Jurnal Inovasi Hasil Pengabdian Masyarakat (JIPEMAS), $\quad$ 4(1), 18 . https://doi.org/10.33474/jipemas.v4i1.7174

Santoso, R. (2020). Review of Digital Marketing \& Business Sustainability of E-Commerce During Pandemi Covid 19 In Indonesia. Jurnal Ilmu Ekonomi Terapan, 36-48. Retrieved from https://www.e-journal.unair.ac.id/JIET/article/view/23614/12950

Suhardi, A. R., Marinda, V. S., Rohendra, T., Putra, I. G., \& Budiawan, A. (2021). Pelatihan Digital Marketing Pada UMKM Binaan KADIN Jawa Barat Dalam Era New Normal. Jurnal Pengabdian, 100-104. Retrieved from http://openjournal.unpam.ac.id/index.php/jpdl/article/view/8792

Suhartati, L., Danuz, S. Z., Sasmita, G. F., Nurjanah, I., \& Herniwati, J. (2021). Penyuluhan Kewirausahaan Dan Bimbingan Teknis Digital Marketing Sebagai Upaya Meningkatkan Penjualan UMKM. Penyuluhan Kewirausahaan dan Bimbingan Teknis Digital, 114-124. Retrieved from http://www.openjournal.unpam.ac.id/index.php/JAMH/article/view/10755 
Sulaksono, J., \& Zakaria, N. (2020). Pendampingan dan Penerapan Strategi Digital Marketing Bagi UMKM Terdampak Pandemi Covid 19. Jurnal Pengabdian Kepada Masyarakat, 604-609. Retrieved from https://ejournal.unma.ac.id/index.php/bernas/article/view/540/322

Sumarsono, A., Nurleha, S., Khasanah, D. U., Wardani, N. N., Wahyuni, Sriyani, S., Listiani, D., \& Kasmawati. (2021). Optimalisasi keterampilan merajut sebagai solusi peningkatan ekonomi warga saat pandemi. Jurnal Inovasi Hasil Pengabdian Masyarakat (JIPEMAS), 4(2), 220-230. https://doi.org/10.33474/jipemas.v4i2.9283

Zulfikar, Mahmudi, A., \& Fannani, M. A. (2020). Marketing Digital bagi Pelaku UMKM Desa Gondangmanis. JURNAL PENGABDIAN MASYARAKAT BIDANG EKONOMI, 16-19. Retrieved from https://ejournal.unwaha.ac.id/index.php/abdimas_ekon/article/view/1006/462 